\title{
Analisis Faktor Determinan Tingkat Partisipasi Pemilih Penyandang Disabilitas Pada Pemilihan Umum 2019
}

\section{Analysis of Determinant Factors on Voter Participation Levels with Disabilities in the 2019 General Election}

\author{
Liza Noviani*, Subhilhar \& Muryanto Amin \\ Program Magister Ilmu Politik, Universitas Sumatera Utara, Indonesia
}

Diterima: 29 Juli 2020; Disetujui: 15 Desember 2020; Diterbitkan: 31 Januari 2021.

\begin{abstract}
Abstrak
Perwujudan nilai demokrasi di Indonesia sebagai aktualisasi kekuasaan berada di tangan rakyaat adalah dengan pelaksanaan pemilihan umum (Pemilu) dan pemilihan kepala daerah. Tahun 2019 meupakan pesta demokrasi untuk masyarakat Kota Banda Aceh karena mengadakan pemilihan kepala daerah (pilkada) dan pemilu serentak 2019. Ketidakberpihakan yang kurang kepada kaum disabilitas termasuk pada pengelolaan aksesbilitas pemilu bagi penyandang disabilitas pada pemilu dan pilkada sebelumnya membuat peneliti tertarik untuk melakukan penelitian aksesbilitas pemilu bagi penyandang disabilitas di Kota Banda Aceh karena mengadakan pemilihan kepala daerah (pilkada) dan pemilu serentak 2019. Penelitian ini menggunakan metode penelitian Deskriptif kualitatif. Penelitian ini memerlukan data-data untuk menyimpulkan hasil penelitian, terdapat dua jenis data yang digunakan dalam penelitian ini yaitu data primer dan data sekunder.Untuk menggali data dan informasi, peneliti akan melakukan melalui tekhnik wawancara dengan informan dan informan kunci, observasi non participant serta melalui studi pustaka dengan mempelajari literatur yang bersumber dari buku, jurnal elektronik, surat kabar, peraturan peraturan dan dokumen - dokumen yang berhubungan dengan topik penelitian.

Kata Kunci: Faktor Determinan; Penyandang Disabilitas; Pemilihan Umum
\end{abstract}

\begin{abstract}
The manifestation of democratic values in Indonesia as the actualization of power in the hands of the people is the implementation of general elections (Pemilu) and regional head elections. 2019 was a democratic party for the people of Banda Aceh City because it held regional head elections (pilkada) and 2019 simultaneous elections. The lack of impartiality for people with disabilities, including the management of election accessibility for persons with disabilities in previous elections and local elections, made researchers interested in conducting election accessibility research. for persons with disabilities in Banda Aceh City for holding regional head elections (Pilkada) and simultaneous elections 2019. This research uses descriptive qualitative research methods. This research requires data to conclude the research results, there are two types of data used in this study, namely primary data and secondary data. To explore data and information, researchers will conduct interviews with key informants and key informants, non-participant observation and through literature study by studying literature sourced from books, electronic journals, newspapers, regulations and documents related to research topics.
\end{abstract}

Keywords: Determinant Factors; Persons with Disabilities; General Election

How to Cite: Noviani, L., Subhilhar., \& Amin. M. (2021). Analisis Faktor Determinan Tingkat Partisipasi Pemilih Penyandang Disabilitas Pada Pemilihan Umum 2019. PERSPEKTIF, 10 (1): 88-99

${ }^{*}$ Corresponding author:

E-mail: lizanoviani@gmail.com

ISSN 2085-0328 (Print) ISSN 2541-5913 (online) 


\section{PENDAHULUAN}

Partisipasi politik di negara-negara yang menerapkan sistem demokrasi merupakan hak setiap warga negara untuk ikut berpartisipasi dalam pemilihan umum (pemilu), termasuk penyandang disabilitas. Setiap orang yang mengalami keterbatasan fisik, intelektual, mental, dan/atau sensorik dalam jangka waktu lama yang dalam berinteraksi dengan lingkungan dapat mengalami hambatan dan kesulitan untuk berpartisipasi secara penuh dan efektif dengan warga negara lainnya berdasarkan kesamaan hak (UU No. 8 Tahun 2016, tentang Penyandang Disabilitas). Pemenuhan hak tersebut merupakan perwujudan prinsip kewarganegaraan inklusif, yaitu terpenuhinya semua hak mereka sebagai warga negara secara adil tanpa memandang identitasnya. Selain kewarganegaraan, salah satu syarat pemilu yang aspiratif dan demokratis adalah pemilu harus inklusif (Artis, 2010).

Inklusivitas adalah prinsip untuk menyertakan pihak lain dalam suatu proses, dalam hal ini keikutsertaan dalam pemilu di semua tahapan. Pemilu inklusif dapat dimaknai sebagai pemilu yang memberikan kesempatan seluas-luasnya kepada setiap warga negara. Pemilih juga harus memenuhi ketentuan yang berlaku serta dijamin menggunakan hak-hak pilihnya (Suharyanto, 2014; Suharyanto, 2016; Zega dkk., 2018; Darmila, 2019; Kusmanto, 2013) Dalam memenuhi hak tersebut harus tanpa adanya hambatan atas dasar agama, suku, ras, jenis kelamin, usia, penyandang disabilitas, kondisi wilayah, status sosial ekonomi, dan lain sebagainya. Dalam pelaksanaan pemilu senantiasa terbuka bagi siapa saja bagi seluruh pemilih, termasuk penyandang disabilitas dalam memberikan suaranya. Dengan demikian keikutsertaan pemilih penyandang disabilitas dalam mewujudkan pemilu menjadi penting untuk menjamin dan memastikan mendapat perlakuan yang sama secara hukum dalam penyelenggaraan pemilu (Aditya, 2019).

Berkaitan dengan partisipasi penyandang disabilitas terdapat suatu slogan yang ada di seluruh dunia, yaitu "nothing about us without us (tidak ada tentang kami tanpa keterlibatan kami)". Slogan ini menunjukkan pentingnya partisipasi mereka dalam segala aspek kehidupan,". Hal tersebut mengisyaratkan bahwa penyandang disabilitas adalah pihak yang paling mengerti akan kebutuhan baik tentang kebijakan publik, program pemerintah, dan lain sebagainya tak akan berarti tanpa melibatkan mereka di dalamnya. Dengan adanya slogan tersebut, maka tidak ada alasan untuk bersikap diskriminatif terhadap penyandang disabilitas karena mereka juga harus diperlakukan sama serta memiliki hak yang sama dengan non-disabilitas lainnya dalam segala aspek kehidupan (Wahyuni, 2018).

Sehubungan dengan pemenuhan hak politik penyandang disabilitas dalam pemilu, Komisi Pemilihan Umum (KPU) bersama dengan pemerintah telah menunjukkan komitmennya. Hal tersebut ditandai dengan adanya Memorandum of Understanding (MoU) tanggal 11 Maret 2013 antara KPU dengan Pusat Pemilihan Umum Akses Penyandang Cacat (PPUA PENCA) sebagai lembaga advokasi hak politik penyandang disabilitas. Dalam MoU tersebut, KPU sepakat akan menyelenggarakan setiap tahapan pemilu secara inklusif, aksesibel, dan non-diskriminatif khususnya bagi penyandang disabilitas.

Keseriusan KPU tersebut diawali dengan melibatkan penyandang disabilitas dalam penyusunan regulasi pada pelaksanaan pemilu 2014. Tujuannya untuk mengidentifikasi dan mengakomodasi setiap kebutuhan dalam pelaksanaan pilkada 2015. Dalam pemilu tersebut mencantumkan data ragam pemilih penyandang disabilitas dalam data pemilih dengan kolom khusus dan keterangan yaitu angka keterangan (1) Disabilitas Daksa; (2) Disabilitas Netra; (3) Disabilitas Rungu/Wicara; (4) Disabilitas Grahita; (5) Disabilitas lainnya. Dengan demikian, mereka memiliki kesempatan yang sama untuk terlibat dalam sistem penyelenggaraan pemilu dari tingkat nasional sampai ke tingkat daerah.

Suksesnya penyelenggaraan pemilu tidak terlepas dari partisipasi pemilih penyandang disabilitas yang merupakan segmen strategis dalam kehidupan demokrasi Indonesia. Hal tersebut telihat dari pengesahan hak-hak mereka melalui UU Nomor 19 Tahun 2011 tentang Pengesahan Convention on The Rights of Person With Disabilities, UU Nomor 8 Tahun 2016 tentang Penyandang Disabilitas, dan UU Nomor 7 Tahun 2017 tentang Pemilihan Umum (Abdillah, 2015).

Bahkan dalam Undang-Undang Nomor 7 Tahun 2017 yang merupakan Undang-Undang 
pemilu 2019 memuat satu pasal akan strategisnya partisipasi pemilih penyandang disabilitas dalam pemilu. Pasal tersebut telah berspektif inklusi dimana adanya keterbukaan bagi penyandang disabilitas yang telah memenuhi syarat sebagai pemilih, untuk dipilih sebagai wakil rakyat di DPR dan DPRD, DPD, presiden dan wakil presiden serta sebagai penyelenggara pemilu baik di KPU, KPU/KIP Provinsi/Kabupaten/Kota, PPK, PPS, KPPS atau pada jajaran Bawaslu. Meskipun telah banyak regulasi tentang pemenuhan hak dan partisipasi pemilih penyandang disabilitas dalam pemilu, namun dalam pelaksanaannya masih banyak hak mereka yang terabaikan. Kondisi tersebut terlihat dari masih rendahnya partisipasi mereka dalam pemilu di beberapa daerah, salah satunya adalah Kota Banda Aceh. Hal ini menunjukkan belum terwujudnya pemilu inklusif daerah tersebut.

Di Indonesia, jumlah penyandang disabilitas belum dapat diketahui secara pasti dikarenakan datanya yang belum akurat. Data tersebut diantaranya; (1) menurut penghitungan World Health Organization (WHO), diperkirakan 10 persen dari penduduk Indonesia (24 juta) adalah penyandang disabilitas; (2) Menurut Pusat Data dan Informasi (Pusdatin) Kementerian Sosial (Kemensos), pada tahun 2010 jumlah penyandang disabilitas di Indonesia adalah 11.580.117 orang; dan (3) Menurut data Kementerian Tenaga Kerja dan Transmigrasi (Kemnakertrans), pada tahun 2010 jumlah penyandang disabilitas di Indonesia adalah 7.126.409 orang. Ketidakakuratan data ini menjadi permasalahan serius, terutama mengenai hak politik mereka yang sering terabaikan. Selain itu, secara statistik pendataan jumlah pemilih disabilitas masih buruk dikarenakan jumlahnya yang selalu kecil. Hal ini menandakan bahwa Indonesia belum ramah dan belum adanya yang menjamin aksesibilitas yang memadai dalam pemenuhan hak pilih mereka khususnya di Tempat Pemungutan Suara (TPS) (Martini dan Yulyana, 2018).

Apabila dilihat dari data penghitungan WHO, Pusdatin Kemensos, dan Kemnakertrans di atas, secara kuantitatif jumlahnya cukup signifikan dan berpotensi untuk mempengaruhi kontestasi dalam proses pemilu. Banyaknya jumlah penyandang disabilitas perlu menjadi perhatian khusus dalam membuat komitmen menyediakan pemilu yang aksesibilitas bagi penyandang disabilitas. Tidak hanya berkaitan dengan akses TPS dan alat bantu kertas suara saja, tetapi juga berkaitan dengan pendataan. Dalam hal ini peran keluarga terdekat dan masyarakat pada saat pendataan menjadi acuan utama. Dimana tidak ada keluarga terdekat atau masyarakat yang menutupi atau bersikap acuh dan malu apabila terdapat anggota keluarga atau anggota masyarakatnya yang menyandang disabilitas. Dengan adanya keterbukaan informasi dari berbagai pihak, maka akan diperoleh data pemilih disabilitas yang lebih akurat.

Terlepas dari buruknya pendataan pemilih dan tidak akuratnya data, isu disabilitas dalam pemilu menjadi penting terutama setelah pilkada serentak tahun 2015 sebagai pemilu pertama yang mempublikasikan partisipasi pemilih disabilitas secara online. Hal tersebut juga didukung dengan rencana strategis (renstra) KPU sebagaimana yang disampaikan melalui Surat Keputusan (SK) KPU Nomor 90/Kpts/KPU/Tahun 2019 tentang Perubahan atas Keputusan KPU Nomor 63/Kpts/KPU/Tahun 2015 tentang Rencana Strategi Komisi Pemilihan Umum (Renstra KPU) Tahun 2015-2019, yang menjelaskan mengenai Indikator Kinerja Utama (IKU) KPU sejak Tahun 2015-2019 adalah meningkatkan kualitas penyelenggaraan pemilu/pemilihan yang demokratis yang salah satunya adalah tercapainya persentase partisipasi pemilih penyandang disabilitas dengan angka $75 \%$. Hal ini menunjukkan adanya keseriusan KPU dalam meningkatkan partisipasi pemilih disabilitas yang diawali dari pilkada serentak 2015. Adanya target tersebut diharapkan dapat memotivasi KPU Kabupaten/Kota di Indonesia untuk dapat juga lebih memperhatikan partisipasi pemilih penyandang disabilitas, sama seperti warga masyarakat nondisabilitas.

Selain itu pada pemilu serentak 2019, KPU juga telah menjamin hak pilih bagi peyandang disabilitas mental atau Orang Dengan Gangguan Jiwa (ODGJ) dengan memasukkan nama mereka ke dalam Daftar Pemilih Tetap (DPT). Hal ini sebagaimana berdasarkan putusan Mahkamah Konstitusi Nomor 135/PUU-XII/2015 tentang hak pilih bagi pengidap gangguan jiwa non-permanen dan atas rekomendasi dari Bawaslu. Didaftarkannya mereka di DPT karena 
gangguan jiwa atau kehilangan ingatan tersebut bersifat non-permanen (episodik). Sehingga KPU mengambil kebijakan harus didaftar di DPT, karena jika tidak didaftar maka pada saat hari pemungutan suara nanti mereka sudah sembuh, pemilih disabilitas mental ini akan kehilangan hak pilihnya.

Sehubungan dengan renstra KPU sebagaimana yang telah dijelaskan sebelumnya, dalam rentang waktu 5 (lima) tahun terakhir yaitu dari Tahun 2015 sampai dengan Tahun 2019, Komisi Independen Pemilihan (KIP) Kota Banda Aceh telah melaksanakan 2 (dua) kali pemilihan serentak yaitu pemilihan kepala daerah (pilkada) serentak 2017 dan pemilu serentak 2019. Pada pilkada serentak 2017, menurut data KIP Aceh total DPT penyandang disabilitas di Propinsi Aceh berjumlah 7.138 pemilih dan untuk Kota Banda Aceh berjumlah 77 pemilih disabilitas yang terdaftar di DPT. Dari jumlah tersebut hanya 40 orang yang menggunakan hak pilihnya pada pilkada 2017. Sehingga angka partisipasi pemilih disabilitas pada saat itu hanya mencapai 52\%.

Pada pemilu serentak 2019, KPU telah menetapkan total DPT penyandang disabilitas berjumlah 1.247.730 pemilih di seluruh wilayah Indonesia. Dari jumlah tersebut, total penyandang disabilitas untuk Provinsi Aceh yang terdaftar dalam DPT berjumlah 11.601 pemilih dan untuk Kota Banda Aceh berjumlah 494 pemilih dengan latar belakang kondisi diantaranya 80 orang (Tuna Daksa), 81 orang (Tuna Netra), 56 orang (Tuna Rungu/Wicara), 60 orang (Tuna Grahita), dan 217 orang (Disabilitas lainnya). Pada hari pemungutan suara terdapat 3 (tiga) orang pemilih penyandang disabilitas yang memilih dengan KTP-elektronik karena tidak terdaftar dalam DPT dan Daftar Pemilih Tetap Tambahan (DPTb) sehingga dimasukkan dalam Daftar Pemilih Khusus (DPK). Dengan demikian total data pemilih penyandang disabilitas pada pemilu 2019 di Kota Banda Aceh adalah 497 orang. Dari 497 pemilih penyandang disabilitas tersebut, hanya 204 orang yang menggunakan hak pilihnya pada pemilu 2019. (Ichsan \& Fadlia, 2018).

Rendahnya partisipasi pemilih disabilitas pada pemilu 2019 di Kota Banda Aceh bukanlah fenomena pertama yang terjadi dalam pemilu di Kota Banda Aceh. Sebagaimana yang telah dijelaskan sebelumnya bahwa pada pilkada
2017, partisipasi pemilih disabilitas di Kota Banda Aceh juga tergolong rendah hanya mencapai 52\%. Sebagai salah satu indikator yang menentukan kualitas dalam pemilu, maka tema mengenai partisipasi politik khususnya partisipasi pemilih penyandang disabilitas penting untuk dibahas. Penelitian ini dapat dijadikan sebagai salah satu barometer terwujudnya pemilu inklusif tentang apakah penyandang disabilitas sebagai bagian dari warga negara telah memperoleh kesempatan yang sama dalam pemilu baik untuk dipilih dan memilih tanpa adanya diskriminasi.

\section{METODE PENELITIAN}

Penelitian ini menggunakan metode kuantitatif. Penelitian kuantitatif dipilih karena peneliti ingin mengetahui apakah faktor pendukung partisipasi politik yang dikemukakan oleh Milbrath berpengaruh positif atau negatif terhadap tingkat partisipasi pemilih penyandang disabilitas pada pemilihan umum 2019 di Kota Banda Aceh. Penelitian ini menggunakan 3 (tiga) variabel, yaitu variabel independen (variabel bebas), variabel intervening (variabel perantara) dan variabel dependen (variabel terikat) (Sugiyono, 2012).

Penelitian ini dilakukan di Kota Banda Aceh, yang terdiri dari 9 (sembilan) Kecamatan. Pilihan lokasi penelitian dipertimbangkan atas beberapa hal, diantaranya: pertama, Banda Aceh merupakan ibukota Propinsi Aceh; kedua, keberadaan asosiasi atau organisasi perkumpulan penyandang disabilitas yang beragam seperti Pertuni (Persatuan Tuna Netra Indonesia), YPAC (Yayasan Penderita Anak Cacat), PPDI (Persatuan Penyandang Disabilitas Indonesia), PPUA Penca (Pusat Pemilihan Umum Akses Penyandang Cacat), GERKATIN (Gerakan untuk Kesejahteraan Tuna Rungu Indonesia) dan lain. Keberadaan ini tentunya dapat memudahkan dalam mendapatkan mitra informan penelitian; Ketiga, banyaknya penyandang disabilitas kurang mampu yang terdapat di kabupaten/kota lain menitipkan keluarganya ke Yayasan tempat penyandang disabilitas yang terdapat di Banda Aceh karena adanya bantuan dari pemerintah Aceh yang tidak dipungut biaya.

Populasi adalah keseluruhan dari subjek penelitian. Sampel dalam penelitian merupakan suatu bagian dari populasi (Arikunto, 2012). Populasi dalam penelitian ini 
adalah semua pemilih penyandang disabilitas yang terdaftar dalam Daftar Pemilih Tetap (DPT) Kota Banda Aceh pada pemilu 2019 sebanyak 497 pemilih. Oleh karena itu, sampel harus memiliki ciri-ciri sebagimana yang dimiliki oleh populasinya. Teknik pengambilan sampel dalam penelitian ini adalah non probability sampling. Teknik pengambilan sampel ini dimana setiap anggota populasi tidak memiliki peluang/kesempatan yang sama untuk dipilih. Untuk pengambilan sampel, penelitian ini menggunakan metode accidental sampling. Metode yang dalam pengambilan sampelnya langsung mengumpulkan data dari unit sampling dan setelah jumlahnya mencukupi maka pengumpulan data dihentikan (Nawawi, 2001).

\section{HASIL DAN PEMBAHASAN \\ Definisi dan Peragaman Penyandang Disabilitas}

Penyandang disabilitas atau sering juga dikenal dengan 'difabel' merupakan istilah baru yang dinilai lebih manusiawi sebagai pengganti istilah lama yaitu 'cacat'. Istilah 'disabilitas' ini muncul sejak diterbitkannya UU Nomor 8 Tahun 2016 tentang Penyandang Disabilitas dimana sebelumnya masih menggunakan istilah 'cacat' sebagaimana yang tercantum dalam UU Nomor 4 Tahun 1997 tentang Penyandang Cacat. Munculnya disabilitas dapat dilatarbelakangi oleh masalah kesehatan yang timbul sejak lahir, penyakit kronis maupun akut, serta cedera yang diakibatkan oleh kecelakaan, perang, kerusuhan, bencana, dan sebagainya. Permasalahan yang sering terjadi pada masyarakat disabilitas adalah sulitnya berinteraksi dengan berbagai hambatan yang dapat menyulitkan partisipasi penuh dan efektif dalam masyarakat berdasarkan kesetaraan dengan yang lainnya. Padahal sejatinya hak mereka adalah sama yaitu pemenuhan hak atas pendidikan, kesehatan, sosial, hukum dan politik.

Sehubungan dengan hak politik, penyandang disabilitas seringkali kurang mendapatkan tempat di lingkungan masyarakat. Namun, harus diakui bahwa sebagian dari mereka mampu bertindak rasional bahkan memiliki sikap kritis. Sehingga tidak ada alasan untuk tidak melibatkan mereka dalam pemilu. Hal ini berdasarkan prinsip "one man, one vote, one value", suara pemilih penyandang disabilitas sama nilainya dengan suara pemilih non-disabilitas. Memilih dalam pemilu merupakan hak setiap warga negara yang sudah memuhi syarat sebagai pemilih yaitu telah berusia 17 (tujuh belas) tahun atau lebih atau sudah/pernah kawin. Hal ini berlaku bagi siapa saja termasuk pemilih penyandang disabilitas sebagai perwujudan prinsip kewarganegaraan inklusif tanpa adanya perlakuan yang bersifat diskriminatif (Nasution \& Marwandianto, 2019).

Pengelompokan ragam disabilitas dilakukan sebagai upaya untuk memfasilitasi dalam menggunakan hak pilihnya pada hari pemungutan suara. Hal ini dilakukan agar fasilitas yang diberikan sesuai dengan kebutuhan dan diharapkan nantinya mereka tidak memiliki kendala di TPS. Pengelompokan kelima ragam disabilitas dalam DPT dilakukan KPU dengan merujuk pada UU Nomor 4 Tahun 1997 tentang Penyandang Cacat, yang terdiri dari: 1) Penyandang cacat fisik, yaitu kecacatan yang mengakibatkan gangguan pada fungsi tubuh (tuna daksa), penglihatan (tuna netra), pendengaran (tuna rungu), dan kemampuan bicara (tuna wicara); 2) Penyandang cacat mental, yaitu kelainan mental dan/atau tingkah laku, baik cacat bawaan atau akibat dari penyakit (tuna grahita); 3) Penyandang cacat fisik dan mental, yaitu keadaan seseorang yang menyandang dua jenis kecacatan sekaligus atau cacat ganda, seperti gangguan pada fungsi tubuh, penglihatan, pendengaran, dan kemampuan berbicara serta mempunyai kelainan mental/tingkah laku sehingga tidak mampu melakukan kegiatan sehari-hari secara layak/wajar (disabilitas lainnya).

Namun setelah keluarnya UU Nomor 8 Tahun 2016 tentang Penyandang Disabilitas, definisi dan klasifikasi penyandang disabilitas tidak lagi merujuk pada UU Nomor 4 Tahun 1997. Sejak pilkada serentak 2017 sampai dengan saat ini terkait penyandang disabilitas merujuk pada Undang-Undang Nomor 8 Tahun 2016. Menurut Undang-Undang tersebut, penyandang disabilitas adalah setiap orang yang mengalami keterbatasan fisik, intelektual, mental, dan/atau sensorik dalam jangka waktu lama (paling singkat 6 bulan dan/atau bersifat permanen) yang dalam berinteraksi dengan lingkungan dapat mengalami hambatan dan kesulitan untuk berpartisipasi secara penuh dan efektif dengan warga negara lainnya berdasarkan kesamaan hak: 1) Penyandang disabilitas fisik, yaitu terganggunya fungsi 
gerak, antara lain: amputasi, lumpuh layuh atau kaku, paraplegi celebral palsy (CP), akibat stroke, akibat kusta, dan orang kercil; 2) Penyandang disabilitas intelektual, yaitu terganggunya fungsi pikir karena tingkat kecerdasan dibawah rata-rata, antara lain: lambat belajar, disabilitas grahita dan down syndrom; 3)Penyandang disabilitas mental, yaitu terganggunya fungsi pikir, emosi, dan perilaku, antara lain: (1) psikososial seperti skizofrenia, bipolar, depresi, anxietas, dan gangguan kepribadian; (2) disabilitas perkembangan yang berpengaruh pada kemampuan interaksi sosial seperti autis dan hiperaktif; 4) Penyandang disabilitas sensorik, yaitu terganggunya salah satu fungsi dari panca indera, seperti disabilitas netra, rungu, dan/atau wicara.

Pada kondisi tertentu, seorang penyandang disabilitas dapat saja mengalami gangguan dari keempat ragam disabilitas diatas secara tunggal, ganda, atau multi dalam jangka waktu lama yang ditetapkan oleh tenaga medis sesuai dengan ketentuan peraturan perundangundangan. Penyandang disabilitas ganda atau multi adalah penyandang disabilitas yang mempunyai dua atau lebih ragam disabilitas, seperti disabilitas runguwicara dan disabilitas netra-tuli (Martini dan Yulyana, 2018).

\section{Partisipasinya Penayandang Disabilitas Pada Pemilu di Kota Banda Aceh}

Kota Banda Aceh merupakan ibukota Provinsi Aceh dan dijadikan sebagai proyek percontohan yang digagas oleh pemerintah pusat karena telah menjadikan kotanya sebagai kota yang ramah terhadap penyandang disabilitas, salah satunya adalah dengan melakukan perbaikan rencana pembangunan jangka panjang maupun menengah. Hal ini mengingat banyaknya penyandang disabilitas di Kota Banda Aceh terutama pasca bencana dahsyat gempa dan tsunami 2004 (Suhendra, 2017).

Berdasarkan data KIP Kota Banda Aceh, jumlah pemilih penyandang disabilitas yang terdaftar dalam Daftar Pemilih Tetap (DPT) pada pilkada 2017 di Kota Banda Aceh adalah sebanyak 77 orang dan pada pemilu 2019 sebanyak 494 orang. Berikut data perbandingan pemilih penyandang disabilitas yang terdaftar dalam DPT pada pilkada 2017 dan pemilu 2019 di Kota Banda Aceh yang tersebar di 9 (sembilan) kecamatan yang ada di Kota Banda Aceh berdasarkan kelompok ragam disabilitasnya.

Tabel Data Perbandingan Pemilih Penyandang Disabilitas yang terdaftar dalam Daftar Pemilih Tetap (DPT) Pilkada 2017 dan Pemilu 2019 di Kota Banda Aceh Menurut Ragam Disabilitasnya

\begin{tabular}{|c|c|c|c|}
\hline No & Ragam Disabilitas & $\begin{array}{c}\text { Pilkada } \\
2017\end{array}$ & $\begin{array}{c}\text { Pemilu } \\
2019\end{array}$ \\
\hline 1 & Disabilitas Daksa & 19 & 81 \\
\hline 2 & Disabilitas Netra & 20 & 81 \\
\hline 3 & Disabilitas Rungu/Wicara & 16 & 57 \\
\hline 4 & DIsabilitas Grahita & 14 & 60 \\
\hline 5 & Disabilitas Lainnya & 8 & 218 \\
\hline \multicolumn{2}{|r|}{ JUMLAH } & 77 & 497 \\
\hline
\end{tabular}

Sumber: KIP Kota Banda Aceh

Tabel di atas menunjukkan bahwa jumlah pemilih penyandang disabilitas yang terdaftar dalam DPT dari tahun 2017 ke tahun 2019 mengalami peningkatan cukup drastis. Hal tersebut disebabkan karena adanya keseriusan dari KIP Kota Banda Aceh dalam pendataan pemilih penyandang disabilitas pada pemilu 2019 yakni diantaranya dengan mendatangi beberapa instansi yang menangani penyandang disabilitas seperti Dinas Sosial, Dinas Kesehatan, dan Rumah Sakit Jiwa di Kota Banda Aceh. Hal ini dilakukan guna sinkronisasi data yang terdapat di ketiga instansi tersebut dengan data pemilih yang dimiliki KIP Kota Banda Aceh. Dari ketiga instansi tersebut, basis data penduduk penyandang disabilitas dari Dinas Sosial Kota Banda Aceh yang paling banyak berpengaruh terhadap data pemilih 
penyandang disabilitas dalam DPT pemilu 2019.

Setelah dilakukan verifikasi/pengecekan terhadap data pemilih yang telah dilakukan pencocokan dan penelitian (coklit) oleh petugas Pemutakhiran Data Pemilih (pantarlih) berdasarkan basis data dari Dinas Kependudukan dan Catatan Sipil Kota Banda Aceh) dengan basis data penyandang disabilitas yang berasal dari Dinas Sosial Kota Banda Aceh. Ternyata banyak dari data pemilih KIP Kota Banda Aceh yang tidak mencantumkan kode ragam disabilitas di keterangannya. Hal inilah menjadi penyebab utama melonjaknya data pemilih penyandang disabilitas pada pemilu 2019 di Kota Banda Aceh. Kemudian pada saat melakukan pencocokan dan penelitian (coklit) ke rumahrumah warga, pantarlih juga selalu menanyakan apakah ada anggota keluarga yang menyandang disabilitas. Selain pendataan yang maksimal, mereka juga melakukan sosialisasi dengan menghimbau masyarakat dan juga pemilih penyandang disabilitas untuk memastikan namanya telah terdaftar dalam DPT pemilu 2019. Beberapa strategi tersebut tidak dilakukan pada pilkada 2017. Hal inilah yang menyebabkan jumlah pemilih penyandang disabilitas dalam DPT pemilu 2019 di Kota Banda Aceh meningkat secara drastis daripada pilkada 2017 (wawancara dengan Vera Sisca HS, pada tanggal 9 Maret 2020).

Meskipun jumlah penyandang disabilitas di Indonesia tidak terlalu banyak, namun partisipasi mereka dalam setiap pemilihan harus dan tetap dijaga tingkatannya sebagai acuan suksesnya demokrasi suatu negara. Saat ini Indonesia semakin serius dan intens untuk memprioritaskan hak penyandang disabilitas termasuk kebutuhan mereka dalam menggunakan hak pilih pada pemilu. Dengan keadaan ini tentu sudah seharusnya KPU dan KPUD/KIP menjadi ujung tombak dalam menyukseskan partisipasi pemilih penyandang disabilitas.

Sebagai penyelenggara pemilu, KPU memiliki tanggung jawab untuk meningkatkan partisipasi pemilih penyandang disabilitas dalam setiap pemilihan dan selalu berusaha untuk mewujudkan pemilu inklusif dengan selalu memfasilitasi mereka agar dapat meyalurkan hak pilihnya. Pemenuhan hak politik bagi penyandang disabilitas tersebut sebagaimana telah diatur dalam UU Nomor 8
Tahun 2016 tentang Penyandang Disabilitas yang termuat dalam Pasal 13 dan 77. Lahirnya UU tersebut mengharuskan KPU bersama dengan KPUD untuk dapat menjunjung tinggi nilai-nilai kesetaraan dan kesempatan yang sama bagi penyandang disabilitas untuk ikut berpartisipasi dalam setiap pemilihan. Kedua lembaga tersebut harus memiliki kepedulian lebih terhadap pemilih penyandang disabilitas agar dapat menjamin kesamaan hak mereka pada setiap perhelatan pemilu.

Berdasarkan hal tersebut, maka sejak pilkada serentak Tahun 2017 KPU mulai mengeluarkan banyak regulasi dalam rangka pemenuhan hak politik penyandang disabilitas dalam pemilihan umum. Hal yang dilakukan lembaga ini seperti melakukan pemaksimalan pendataan pemilih, memberikan sosialisasi dan simulasi mengenai kesamaan hak politik bagi penyandang disabilitas. Selain itu, KPU juga memberikan pelayanan terhadap penyandang disabilitas dalam pemilu. Dengan melibatkan penyandang disabilitas serta melakukan rekrutmen relawan demokrasi dan melibatkan mereka sebagai petugas dalam pelaksanaan pemilu serta menyediakan sarana dan prasarana TPS yang aksesibel.

Selain itu, sejak pilkada serentak 2015 KPU juga telah menjadikan partisipasi pemilih penyandang disabilitas sebagai salah satu Indikator Kinerja Utamanya (IKU). Sebagaimana yang disampaikan melalui Surat Keputusan (SK) KPU Nomor 90/Kpts/KPU/Tahun 2019 tentang Perubahan atas Keputusan KPU Nomor 63/Kpts/KPU/Tahun 2015 tentang Rencana Strategi Komisi Pemilihan Umum (Renstra KPU) Tahun 2015-2019. SK tersebut memuat penjelasan mengenai Indikator Kinerja Utama (IKU) KPU sejak Tahun 2015-2019 adalah meningkatkan kualitas penyelenggaraan pemilu/pemilihan yang demokratis. Salah satu indikatornynya adalah tercapainya persentase partisipasi pemilih penyandang disabilitas dengan angka 75\%. Hal ini menunjukkan bahwa KPU telah menjadikan program nasionalnya sejak dari pilkada serentak 2015 sampai pemilu berikutnya untuk dapat meningkatkan partisipasi pemilih penyandang disabilitas dengan angka 75\%.

Pemilu 2019 merupakan pemilu pertama yang dilakukan secara serentak, yaitu pemilihan legislatif dilaksanakan sekaligus dengan pemilihan presiden pada tanggal dan 
hari yang sama yaitu 17 April 2019. Pemilu serentak ini merupakan pelaksanaan atas keputusan Mahkamah Konstitusi Nomor 14/PUU-11/2013 tentang Pemilu Serentak (Ihsanuddin, 2014). Pada pemilu 2019, total sebanyak 440 calon legislatif (caleg) memperebutkan 30 (tiga puluh) kursi di Dewan Perwakilan Rakyat Kota (DPRK) Banda Aceh (Aceh, 2018). Para caleg ini harus bertarung dalam meraih simpati pemilih yang terdaftar dalam DPT sejumlah 157.421 orang yang tersebar di 9 (sembilan) kecamatan Kota Banda Aceh. Total suara sah pada pemilu 2019 di Kota Banda Aceh adalah 107.280 suara dengan tingkat partisipasi pemilih sebanyak 78,63\%.

Diantara 20 partai politik peserta pemilu 2019 di Kota Banda Aceh, terdapat 1 (satu) orang penyandang disabilitas yang mencalonkan diri sebagai bakal calon legislatif anggota DPRK Banda Aceh dari Partai Bulan Bintang (PBB) dengan daerah pemilihan (Dapil) Banda Aceh 4 (Kecamatan Banda Raya dan Jaya Baru) yang bernama Hamdanil. Hamdanil merupakan caleg tuna netra pertama dan satu-satunya penyandang disabilitas di Aceh yang mencalonkan diri sebagai caleg. Meskipun belum berhasil memperoleh kursi di DPRK Banda Aceh, namun keikutsertaannya sebagai caleg adalah salah satu contoh telah terwujudnya pemilu inklusif di Kota Banda Aceh.

Adapun total 30 kursi DPRK Banda Aceh pada pemilu 2019 diraih oleh 9 (sembilan) partai politik diantaranya Partai Gerakan Indonesia Raya 4 kursi $(13,67 \%)$, Partai Golongan Karya 3 kursi $(7,84 \%)$, Partai Nasional Demokrat 3 kursi $(10,62 \%)$, Partai Keadilan Sejahtera 5 kursi $(15,74 \%)$, Partai Persatuan Pembangunan 2 kursi (5,60\%), Partai Amanat Nasional 5 kursi $(13,51 \%)$, Partai Demokrat 5 kursi (11,13\%), Partai Aceh 2 kursi $(7,27 \%)$, dan Partai Nanggroe Aceh 1 kursi (6,55\%). Dari 30 anggota DPRK Banda Aceh hasil pemilu 2019, laki-laki berjumlah 26 orang dan perempuan 4 orang. Berikut grafik perolehan kursi dan jumlah suara sah partai politik anggota DPRK Banda Aceh pada pemilu 2019.

\section{Faktor Determinan Rendahnya Pemilih Penyandang Disabilitas Pada Pemilu 2019 Kota Banda Aceh}

Berdasarkan hasil uji analisis regresi linear berganda, dan uji parsial (uji statistik t) dapat disimpulkan bahwa variabel rangsangan politik dalam model penelitian ini memiliki pengaruh yang positif dan signifikan terhadap partisipasi pemilih penyandang disabilitas. Berdasarkan uji analisis regresi linear berganda nilai koefisien rangsangan politik bernilai positif yaitu 0,110 sehingga diketahui bahwa rangsangan politik memiliki pengaruh yang positif terhadap partisipasi pemilih penyandang disabilitas. Kemudian berdasarkan nilai signifikansi rangsangan politik sebesar 0,026 yang lebih kecil dari 0,05 (Sig. $<\alpha$ ) dan nilai $t_{\text {hitung }} 2,258>$ nilai $t_{\text {tabel }} 1,986$ menunjukkan bahwa rangsangan politik secara parsial berpengaruh positif dan signifikan terhadap partisipasi pemilih penyandang disabilitas pada pemilu 2019 di Kota Banda Aceh. Secara teoritis, dengan adanya rangsangan politik maka orang mau berpartisipasi dalam kehidupan politik. Hasil ini memberikan bukti empiris bahwa semakin sering penyandang disabilitas menerima perangsang politik, yakni dengan aktif mengikuti kegiatan politik maka dengan sendirinya akan menumbuhkan minat/kemauannya untuk berpartisipasi dalam kehidupan politik (Maran, 2007).

Secara teoritis, karakteristik pribadi berkaitan dengan kepedulian sosial seseorang terhadap permasalahan sosial, politik, ekonomi, sosial budaya, dan hankam. Biasanya mau terlihat dalam aktivitas politik (Maran, 2007, p. 97). Penyandang disabilitas yang memiliki kepedulian sosial terhadap permasalahan sosial, politik, ekonomi tentu akan mau terlibat dalam aktivitas atau organisasi politik. Dengan adanya kemauan penyandang disabilitas untuk terlibat dalam organisasi maka secara tidak langsung akan dapat menumbuhkan rasa percaya diri mereka dalam berinteraksi dengan lingkungan.

Lingkungan politik yang kondusif membuat orang dengan senang hati berpartisipasi dalam kehidupan politik. Hasil ini memberikan bukti empiris bahwa situasi lingkungan yang demokratis dalam kehidupan penyandang disabilitas sangat mempengaruhi mereka untuk mau berpartisipasi menggunakan hak pilihnya, misalnya adanya kepedulian baik dari keluarga, masyarakat dan lingkungan sekitar untuk mengajak mereka menggunakan hak pilihnya ke TPS serta adanya keramahan dari petugas KPPS dalam menangani penyandang disabilitas (Maran, 2007). 
Selain itu lingkungan politik juga dapat dikaitkan dengan tersedianya aksesibilitas yang baik bagi penyandang disabilitas saat menuju ke TPS. Dengan menempatkan penyandang disabilitas di lokasi TPS yang paling dekat dengan tempat tinggalnya akan mendukung mereka untuk berpartisipasi pada pemilu 2019. Keberadaan TPS yang jauh dari tempat tinggal penyandang disabilitas berkaitan erat dengan ketersediaan sarana transportasi yang mendukung untuk menggunakan hak pilihnya di TPS khususnya bagi penyandang disabilitas netra dan daksa. Adanya keinginan dari dalam diri mereka untuk memilih namun tidak dibarengi dengan ketersediaan transportasi untuk menuju ke TPS maka dapat mengurungkan niat mereka untuk menggunakan hak pilihnya dalam pemilu.

Pada pemilu 2019 bahwa rendahnya partisipasi pemilih penyandang disabilitas pada pemilu 2019 di Kota Banda Aceh karena tidak adanya biaya/transportasi ke TPS sehingga mereka memutuskan untuk tidak memilih (golput). Sedangkan menurut Zulfa Hendra (penyandang disabilitas daksa) bahwa "Rendahnya partisipasi pemilih penyandang disabilitas pada pemilu 2019 berkaitan dengan aksesibilitas yakni KIP belum menfasilitasi alat atau monitor di TPS untuk disabilitas rungu demi kelancaran mereka pada saat dipanggil ke bilik suara. Selama ini KIP hanya memperhatikan fasilitas di TPS untuk disabilitas netra dan daksa saja seperti template braille, form pendamping, TPS tidak ditempatkan di tempat yang berbukit-bukit, dan lain sebagainya" (wawancara dengan Zulfa Hendra, pada tanggal 26 April 2020).

Hasil ini membuktikan bahwa semakin sering seorang penyandang disabilitas mengikuti sosialisasi politik sebagai bentuk pendidikan politik maka akan semakin besar pemahaman dan pengetahuannya terhadap politik yang pada akhirnya dapat mempengaruhi pemilih disabilitas untuk berpartisipasi dalam kehidupan politik. Faktor pendidikan politik merupakan hal penting yang harus dimiliki oleh semua pemilih yang sudah memenuhi syarat menurut Undang-Undang tanpa membedakan status dan golongan. Demikian halnya juga dengan penyandang disabilitas harus difasilitasi untuk mendapatkan haknya sebagai warga negara yakni memperoleh informasi yang berkaitan dengan kegiatan politik. Hal ini sebagai wujud tanggung jawab KPU sebagai penyelenggara pemilu untuk menyelenggarakan kegiatan yang berkaitan dengan upaya pemenuhan pendidikan politik bagi pemilih.

Dalam hal ini, penyebab rendahnya partisipasi pemilih penyandang disabilitas di Kota Banda Aceh sebagaimana hasil wawancara peneliti dengan Hamdanil bahwa "KIP Kota Banda Aceh belum melakukan sosialisasi pemilu secara menyeluruh ke penyandang disabilitas, artinya KIP hanya melakukan sosialisasi kepada disabilitas yang aktif dalam suatu komunitas/organisasi sedangnya yang tidak aktif mengikuti organisasi tidak pernah diundang untuk mengikuti sosialisasi pemilu 2019" (wawancara dengan Hamdanil, pada tanggal 26 April 2020).

Berdasarkan hasil uji analisis regresi linear berganda, dan uji parsial (uji statistik $t$ ) dapat disimpulkan bahwa variabel karakteristik sosial dalam memiliki pengaruh yang positif dan signifikan terhadap partisipasi pemilih penyandang disabilitas. Berdasarkan uji analisis regresi linear berganda nilai koefisien pendidikan politik bernilai positif yaitu 0,136 sehingga dapat diketahui bahwa karakteristik sosial memiliki pengaruh yang positif terhadap partisipasi pemilih penyandang disabilitas. Kemudian berdasarkan nilai signifikansi karakteristik sosial sebesar 0,000 yang lebih kecil dari 0,05 (Sig. $<\alpha$ ) dan nilai $t_{\text {hitung }} 4,124>$ nilai $t_{\text {tabel }} 1,986$ menunjukkan bahwa karakteristik sosial secara parsial berpengaruh positif dan signifikan terhadap partisipasi pemilih penyandang disabilitas pada pemilu 2019 di Kota Banda Aceh.

Hasil ini menunjukkan bahwa usia, tingkat pendidikan, dan besarnya pendapatan sangat berpengaruh pada partisipasi politik penyandang disabilitas. Semakin tua umur seorang penyandang disabilitas, akan semakin sulit untuk terlibat dalam kegiatan politik. Semakin rendah tingkat pendidikan dari seorang penyandang disabilitas akan mempengaruhi pengetahuannya dalam mencari tahu informasi seputar politik, dan semakin rendah pendapatan seorang penyandang disabilitas juga akan semakin sulit untuk penyandang disabilitas pergi ke TPS. Sehingga dapat disimpulkan bahwa usia, tingkat pendidikan dan penghasilan sangat mempengaruhi penyandang disabilitas untuk 
dapat berpartisipasi dalam pemilu (Fikri, 2019).

Berdasarkan hasil analisis jalur diketahui bahwa besarnya koefisien regresi pengaruh tidak langsung rangsangan politik terhadap partisipasi pemilih penyandang disabilitas melalui karakteristik sosial lebih kecil dari pengaruh langsungnya $(0,043<0,110)$. Berdasarkan hasil analisis jalur dengan uji sobel diketahui bahwa nilai $t_{\text {hitung }}$ uji sobel = 1,904 lebih kecil dari $t_{\text {tabel }}=1,96$ dengan tingkat signifikansi 5\%. Dengan demikian dapat disimpulkan bahwa karakteristik sosial tidak dapat dijadikan sebagai variabel intervening dalam pengaruh rangsangan politik terhadap partisipasi pemilih penyandang disabilitas pada pemilu 2019 di Kota Banda Aceh. Sehingga hipotesis yang menyatakan bahwa karakteristik sosial dapat dijadikan variabel intervening dalam pengaruh rangsangan politik terhadap partisipasi pemilih penyandang disabilitas pada pemilu 2019 atau $\mathrm{H}_{0}$ diterima.

Berdasarkan hasil analisis jalur diketahui bahwa besarnya koefisien regresi pengaruh tidak langsung karakteristik pribadi terhadap partisipasi pemilih penyandang disabilitas melalui karakteristik sosial lebih kecil dari pengaruh langsungnya $(0,050<0,117)$. Berdasarkan hasil analisis jalur dengan uji sobel diketahui bahwa nilai $t_{\text {hitung }}$ uji sobel $=$ 1,936 lebih kecil dari $t_{\text {tabel }}=1,96$ dengan tingkat signifikansi 5\%. Dengan demikian dapat disimpulkan bahwa karakteristik sosial tidak dapat dijadikan sebagai variabel intervening dalam pengaruh karakteristik pribadi terhadap partisipasi pemilih penyandang disabilitas pada pemilu 2019 di Kota Banda Aceh. Sehingga karakteristik sosial dapat dijadikan variabel intervening dalam pengaruh karakteristik pribadi terhadap partisipasi pemilih penyandang disabilitas pada pemilu 2019 atau $\mathrm{H}_{0}$ diterima.

Berdasarkan hasil analisis jalur dapat diketahui bahwa besarnya koefisien regresi pengaruh tidak langsung situasi atau lingkungan politik terhadap partisipasi pemilih penyandang disabilitas melalui karakteristik sosial lebih kecil dari pengaruh langsungnya $(0,041<0,097)$. Namun berdasarkan hasil analisis jalur dengan uji sobel, dapat diketahui bahwa nilai $t_{\text {hitung }}$ uji sobel $=1,964$ lebih besar dari $t_{\text {tabel }}=1,96$ dengan tingkat signifikansi 5\%. Dengan demikian dapat disimpulkan bahwa karakteristik sosial dapat dijadikan sebagai variabel intervening dalam pengaruh situasi atau lingkungan politik terhadap partisipasi pemilih penyandang disabilitas pada pemilu 2019 di Kota Banda Aceh dengan koefisien mediasi sebesar 0,041. Sehingga dijadikan variabel intervening dalam pengaruh situasi atau lingkungan politik terhadap partisipasi pemilih penyandang disabilitas pada pemilu 2019.

Berdasarkan hasil analisis jalur dapat diketahui bahwa besarnya koefisien regresi pengaruh tidak langsung pendidikan politik terhadap partisipasi pemilih penyandang disabilitas melalui karakteristik sosial lebih kecil dari pengaruh langsungnya $(0,058<$ $0,146)$. Namun berdasarkan hasil analisis jalur dengan uji sobel, dapat diketahui bahwa nilai $t_{\text {hitung }} u j i$ sobel $=2,00$ lebih besar dari $t_{\text {tabel }}=1,96$ dengan tingkat signifikansi 5\%. Dengan demikian dapat disimpulkan bahwa karakteristik sosial dapat dijadikan sebagai variabel intervening dalam pengaruh pendidikan politik terhadap partisipasi pemilih penyandang disabilitas pada pemilu 2019 di Kota Banda Aceh dengan koefisien mediasi sebesar 0,058. Sehingga karakteristik sosial dapat dijadikan variabel intervening dalam pengaruh pendidikan politik terhadap partisipasi pemilih penyandang disabilitas pada pemilu 2019.

Hal tersebut menunjukkan bahwa dalam pendidikan politik, karakteristik sosial (usia, pendidikan dan penghasilan) seorang penyandang disabilitas dapat mempengaruhi partisipasinya dalam pemilu. Artinya, penyandang disabilitas yang berusia lanjut dengan tingkat pendidikan dan penghasilan yang rendah biasanya tidak mau mengikuti pendidikan politik baik yang diberikan oleh lembaga formal seperti KPU/KIP maupun organisasi.

\section{SIMPULAN}

Berdasarkan hasil penelitian ini, pendidikan politik menjadi faktor determinan pertama yang mempengaruhi rendahnya tingkat partisipasi pemilih penyandang disabilitas dalam pemilu. Hal ini berkaitan dengan sosialisasi pemilu baik yang dilaksanakan oleh KIP Kota Banda Aceh sebagai penyelenggara pemilu maupun oleh komunitas/organisasi penyandang disabilitas. Dalam hal ini telah melaksanakan beberapa kali sosialisasi kepada penyandang disabilitas. 
Namum hanya yang tergabung dalam komunitas/organisasi saja yang sering mengikuti sosialisasi.

Beberapa faktor determinan yang mempengaruhi rendahnya tingkat partisipasi pemilih penandang disabilitas dalam pemilu 2019 di Kota Banda Aceh. Pertama, pendidikan politik menjadi faktor yang pertama. Hal ini berkaitan dengan sosialisasi pemilu baik yang dilaksanakan oleh KIP Kota Banda Aceh maupun oleh komunitas/organisasi penyandang disabilitas. Kedua, situasi lingkungan yang demokratis di tempat mereka memilih, seperti akses ke TPS, keramahan dari petugas KPPS, dan lain sebagainya. Ketiga, karakteristik pribadi berkaitan dengan kepedulian sosial terhadap suatu permasalahan dan kemauan untuk mau terlibat dalam suatu aktivitas atau organisasi. Namun dalam hal ini tidak memiliki pengaruh yang cukup besar sebagai faktor yang menyebabkan rendahnya partisipasi pemilih penyandang disabilitas. Dan terakhir keempat, rangsangan politik bukan menjadi faktor yang menyebabkan rendahnya partisipasi mereka sebagai pemilih. Hal ini dikarenakan mereka sudah mulai banyak mengikuti diskusi politik maupun informasi pemilu melalui media baik media cetak maupun elektronik.

Rangsangan, lingkungan, dan pendidikan politik serta karakteristik pribadi maupun karakteristik sosial memiliki pengaruh yang positif dan signifikan terhadap partisipasi pemilih penyandang disabilitas pada pemilu 2019 di Kota Banda Aceh. Artinya semakin banyak yang diterima oleh penyandang disabilitas, maka akan semakin tinggi pula partisipasi mereka untuk menggunakan suaranya dalam pemilu. Sementara itu, karakteristik sosial tidak bisa dijadikan sebagai variabel intervening dalam pengaruh karakteristik pribadi terhadap partisipasi mereka pada pemilu 2019 di Kota Banda Aceh.

\section{DAFTAR PUSTAKA}

Abdillah, J. (2015). Pelaksanaan Pemilu Yang Aksesibel dan Non-Diskriminasi Sebagai Upaya Pemenuhan Hak-Hak Politik Penyandang Disabilitas. Jurnal HAM, Vol. 6, No. 1, 39-49.

Aditya, d. (2019). Tata Kelola Pemilu di Indonesia. Jakarta: Komisi Pemilihan Umum Republik Indonesia.

Arikunto, S. (2012). Prosedur Penelitian: Suatu Pendekatan Praktek. Jakarta: Rineka Cipta.
Artis. (2010). Eksistensi Partai Politik dan Pemilu Langsung Dalam Konteks Demokrasi di Indonesia. Jurnal Sosial Budaya, Vol. 9, No. 1, 59-80.

Fahmi Al Ichsan, Faradilla Fadlia. (2018). Aksebilitas Tempat Pemungutan Suara (TPS) dan Implikasinya Terhadap Persentase Pemilih Disabilitas. Jurnal Ilmiah Mahasiswa FISIP Unsyiah, Vo. 3, No. 3, tanpa halaman.

Fikri, A. M. (2019). Partisipasi Politik Penyandang Sidabilitas Pada Pemilihan Umum Kepala Daerah (Pilkada) Kota Payakumbuh Tahun 2017. Jurnal Demokrasi dan Politik Lokal, Vol. 1, No. 1, 44-67.

Hilmi Ardani Nasution; Marwandianto. (2019). Memilih dan Dipilih, Hak Politik Penyandang Disabilitas Dalam Kontestasi Pemilihan Umum: Studi Kasus Daerah Istimewa Yogyakarta. Jurnal HAM, Vol. 10. No 2, 161178.

Ihsanuddin. (2014, Januari 23). Ini Alasan MK Putuskan Pemilu Serentak 2019. Retrieved from Kompas.com: https://nasional.kompas.com/read/2014/0 1/23/1536382/Ini.Alasan.MK.Putuskan.Pem ilu.Serentak.2019

Maran, R. R. (2007). Pengantar Sosiologi Politik. Jakarta: Rineka Cipta.

Nawawi, H. (2001). Metode Penelitian Bidang Sosial. Yogyakarta: Gadjah Mada University Press.

Nelly Martini dan Eka Yulyana. (2018). Aksebilitas Pemilu Bagi Penyandang Disabilitas di Kecamatan Karawang Timur Kabupaten Karawang Pada Pemilihan Gubernur Jawa Barat Tahun 2018. Jurnal Politikom Indonesia, Vol. 3, No. 2, 163-178.

Sri Wahyuni, A. K. (2018, Mei 17). Membangun Pemilu Inklusif. Retrieved from lintas24.com: https://lintas24.com/membangun-pemiluinklusif.html

Sugiyono. (2012). Metode Penelitian Kuantitatif dan R\&D. Bandung: Alfabets.

Suhendra, A. (2017). Strategi Pemerintahan Kota Banda Aceh dan Kota Surakarta dalam Mewujudkan Kota Ramah Disabilitas. Jurnal Matra Pembaruan, Vol. 1, No. 3, 131-141.

Suharyanto, A., (2014). Partisipasi Politik Masyarakat Tionghoa dalam Pemilihan Kepala Daerah, JPPUMA: Jurnal Ilmu Pemerintahan dan Sosial Politik UMA (Journal of Governance and Political UMA), 2 (2): 166-175

Suharyanto, A., (2016), Surat Kabar Sebagai Salah Satu Media Penyampaian Informasi Politik pada Partisipasi Politik Masyarakat, Jurnal Administrasi Publik, 6 (2): 123-136.

Zega, M.A. Muda, I. Batubara, B.M. \& Suharyanto, A. (2018). Pengaruh Program Rumah Pintar Pemilu Terhadap Partisipasi Politik 
Masyarakat Pada Kantor Komisi Pemilihan Umum Kota Medan, PERSPEKTIF, 7 (2): 60 65.

Darmila, L. Ivanna, J. \& Iqbal, M. (2019) Perilaku Partisipasi Politik Masyarakat Desa Gunung Tua Tonga pada Pemilihan Bupati/Wakil Bupati Tahun 2013. PERSPEKTIF, 8 (2): 5871.

Kusmanto, H., (2013). Peran Badan Permusyawaratan Daerah dalam Meningkatkan Partisipasi Politik Masyarakat,
JPPUMA: Jurnal Ilmu Pemerintahan dan Sosial Politik UMA (Journal of Governance and Political UMA), 1 (1): 41-47.

Aceh, K. K. (2018, September 21). Pengumuman Daftar Calon Tetap (DCT) Anggota DPRK Banda Aceh. Retrieved from KIP Kota Banda Aceh:

ttps://kip.bandaacehkota.go.id/pengumuma n-daftar-calon-tetap-dct-anggota-dprkbanda-aceh/ 